\title{
Gênero nas ações e resistências ao modelo de desenvolvimento imposto em Barcarena, Pará*
}

\author{
Rosa Acevedo Marin** \\ Rosane de Oliveira Martins Maia***
}

\section{Resumo}

As diversas etapas de instalação do complexo de mineração em Barcarena, Pará, têm significado para as comunidades tradicionais processos de expropriação, deslocamentos e a convivência com os efeitos cumulativos dos crimes ambientais praticados pelas empresas envolvidas. A existência e o modo de vida dos homens e mulheres foram alterados drasticamente pelo projeto de desenvolvimento. Este artigo aborda as estratégias de resistência de mulheres e homens ao modelo de desenvolvimento imposto. As memórias e vozes de grupos de mulheres contêm o envolvimento em luta por direitos étnicos, territoriais $e$ as estratégias de permanência e de retorno às suas territorialidades específicas. Scott $(1995,2001)$ e Brah (2006) apoiam uma perspectiva descritiva da especificidade das mulheres de comunidades tradicionais abordadas.

Palavras-chave: Gênero, Desenvolvimento, Comunidades Tradicionais, Territorialidades, Conflito Socioambiental.

\footnotetext{
* Recebido em 10 de janeiro de 2018, aceito em 20 de setembro de 2018.

** Professora de Antropologia Universidade Federal do Pará; pesquisadora do Projeto Nova Cartografia Social da Amazônia, Belém, PA, Brasil. rosaacevedomarin@gmail.com
**** Professora de História da Escola de Tenente Rêgo Barros/ETRB/Diretoria de Ensino da Força Aérea Brasileira. Belém, PA. historiarosane@hotmail.com


Gender in Actions and Resistance to The Model of Development Imposed in Barcarena, Pará

\begin{abstract}
The many steps of the installation of a mining complex in Barcarena, Pará, have led traditional communities to experience processes of expropriation, displacements and the cumulative effect of environmental crimes committed by companies involved with the project. The existence and ways of living of men and women were drastically changed by this development project. This article addresses resistance strategies of women and men against this imposed project of development. The memories and voices of group of women encompass involvement in the fight for ethnic and territorial rights and strategies for remaining in and returning to their specific territorialities. Scott $(1995,2001)$ and Brah (2006) support a descriptive perspective on the specificity of women from these traditional communities.
\end{abstract}

Keywords: Gender, Development, Traditional Communities, Territorialities, Socio-environmental conflict. 


\section{Introdução}

As ideias e os argumentos que percorrem este artigo não são radicalmente novos, pois milhares de páginas foram escritas, debatidas e consagradas no mundo acadêmico para expor a violência do desenvolvimento $e$ os eventos, dificilmente explicáveis, ocorridos e reconhecidos em seu nome no planeta, que afetam diretamente realidades locais. O que se busca aqui é frisar relações sociais e políticas menos percebidas, por exemplo, quando se tenta compreender as mudanças $e$ as transformações na existência de povos e comunidades tradicionais (Almeida, 2008); as desigualdades sociais de classe, gênero, a desestruturação de formas de existência e a negação de futuro para uma e outra geração.

As territorialidades específicas ${ }^{1}$ de comunidades tradicionais da Vila de Conde/Distrito Industrial e as comunidades quilombolas que vivem em torno do rio Murucupi, na Vila dos Cabanos, localizadas no Município de Barcarena, foram afetadas a partir da década de 1970, com a instalação do complexo de mineração Albrás-Alunorte, $e$ foi dado início ao quadro de conflitos sociais $e$ ambientais no município, em que as comunidades tradicionais experimentaram processos de expropriação, deslocamento e os efeitos da poluição do solo e das águas provocados pelos crimes ambientais praticados pelas empresas mineradoras na região.

As observações aqui referidas possuem como alvo concreto as versões de projetos de desenvolvimento instalados no município de Barcarena, no estado do Pará, e as experiências de grupos de mulheres $e$ homens diante dos agentes do projeto (empresários, gerentes, técnicos, consultores na área de

1 Com base em Almeida (2008:29,51), indicamos o significado de "territorialidades específicas consideradas como resultantes de diferentes processos sociais de territorialização e como delimitando dinamicamente terras de pertencimento coletivo que convergem para um território"; noção referida às "delimitações, mas definitivas ou contingências, dependendo da correlação de força em cada situação social de antagonismo". Portanto, a partir desta noção apreendem-se processos sociais e políticos em tempo e espaços diversos. 
desenvolvimento empresarial e comunitário), da burocracia empresarial (institutos, empresas de consultoria para executar segmentos do projeto), da burocracia estatal (companhias de desenvolvimento, órgãos fundiários, judiciários e policiais, cada um responsável pela execução de ações de expropriação, remanejamento, realocação) e de instituições públicas de defesa de direitos (MPE, MPF). ${ }^{2}$

$\mathrm{O}$ ato primo dos gestores dos projetos é identificar as comunidades tradicionais como empecilho à livre expansão $e$ à ampliação dos interesses dos grupos econômicos que atuam no território, de forma enfática, quando estas procedem a constituirse como agentes políticos.

Mulheres engajadas nessa reação contribuem para as ações coletivas das comunidades e o fortalecimento dos movimentos sociais. Por meio das memórias e vozes das mulheres, percebemos as lutas por direitos, as estratégias de permanência e de retorno aos territórios.

Os posicionamentos, as ações e as vozes das mulheres em Barcarena só se fizeram conhecer recentemente quando, por iniciativa e persistência delas junto ao Ministério Público Federal, foram introduzidos e movidos processos que obrigam o Estado ao reconhecimento de direitos territoriais, étnicos e ambientais. As práticas políticas das mulheres conseguem contestar e romper, mesmo que pontualmente, com estratégias de poder entendidas como o conjunto dos meios operados para fazer funcionar ou manter um dispositivo de poder, na interpretação de Foucault (2008).

2 Este artigo incorpora trabalhos de pesquisa realizados pelas autoras entre 2013 e 2015 para elaboração de cinco relatórios histórico-antropológicos solicitados pelo MPF, e pesquisa de campo e em instituições fundiárias desenvolvida por Rosane Martins Maia para elaboração da tese defendida em 2017. Ressaltamos que na prática desta pesquisa foi recorrente a participação das pesquisadoras como acompanhantes e observadoras de audiências no Ministério Público Federal, na Prefeitura Municipal de Barcarena e na Superintendência do Patrimônio da União (SPU) para abordar questões e reivindicações coletivas. 
O que se procura é reconhecer os efeitos sociais, ambientais, muitos deles ignorados e, frequentemente negados, sobre grupos sociais identificados como extrativistas, pescadores, sitiantes, moradores, trabalhadores da cidade ou daqueles mobilizados por uma política identitária autoidentificados como quilombolas indígenas, ribeirinhos, atingidos pelo projeto de desenvolvimento; e descrever as resistências das comunidades tradicionais, sob as vozes de suas lideranças femininas.

\section{Atualização da reflexão sobre desenvolvimento}

A lógica econômica dominante rotulada de desenvolvimento (no capitalismo e no socialismo) produz e reproduz desigualdades, conflitos, dominação e destruição de sociedades, culturas $e$ ambientes. A reflexão sobre desenvolvimento, particularmente sobre desenvolvimento da Amazônia, elaborada por Almeida (2014) insta a sua atualização quando frisa que o planejamento público trabalha dentro da lógica dualista que separa "tradicional" e "moderno" e associa o desenvolvimento ao "crescimento econômico"; esse planejamento ignora os movimentos sociais e o seu propósito de criar modalidades de desenvolvimento. Oliveira (2014:212) focaliza as ideologias em voga e seus efeitos:

Ideologias novas como a do desenvolvimento sustentado ou como a de expansão de formas de participação democrática são, quase sempre, revertidas e transformadas pela manipulação e dominação de grupos privilegiados. Então, o antropólogo tem a obrigação de refletir não só sobre as ideias e sobre o que os homens pensam que fazem, mas também sobre o que eles fazem concretamente, $e$ entender por que eles pensam que fazem, e por que eles constroem as ideias.

Na década de setenta, o projeto de desenvolvimento para a Amazônia esteve vinculado ao Programa de Polos Agropecuário e Agrominerais da Amazônia (POLAMAZÔNIA) que teve entre suas vertentes a criação do polo minerador configurado no Projeto 
Grande Carajás (PGC), no qual foi inserido o complexo de mineração Albrás/Alunorte, implantado em Barcarena.

Conforme acordo entre Brasil e Japão ${ }^{3}$, o governo brasileiro realizaria as obras e os serviços necessários à implantação do Complexo Albrás-Alunorte. Nesse arranjo econômico e político, o Estado garantiu o investimento em infraestrutura e a construção da hidrelétrica de Tucuruí, facilitando a exploração dos recursos naturais da região. Por meio do Programa de Desenvolvimento Especial, criado em 1978, coube à SUDAM analisar, em níveis regional e local, a execução e a instalação de projetos necessários ao funcionamento das empresas do complexo minerador. $\mathrm{O}$ documento intitulado Complexo Albrás/Alunorte informa a área de abrangência, de aproximadamente 19 mil hectares, apta para instalação das unidades industriais da Alunorte, constituída pela associação nipo-brasileira e o sistema da Companhia Vale do Rio Doce representaria o segmento econômico nacional. A área, em que estariam integradas diversas unidades industriais, disporia de um núcleo urbano com "capacidade de absorver 40 a 50 mil habitantes", de um porto denominado Vila do Conde, e de uma subestação distribuidora da Eletronorte para fornecer "energia necessária ao pleno funcionamento do projeto, além de um distrito industrial e da área de proteção ecológica" (Brasil, 1979:1).

O governo brasileiro por meio de suas agências de desenvolvimento reorganizou o território destinado aos empreendimentos: com políticas de expropriação "arrumaram" o território a ser explorado pelo mercado internacional, deslocando os sitiantes, através da Companhia do Desenvolvimento Industrial do Estado do Pará - CDI e da Companhia de Desenvolvimento de Barcarena - CODEBAR. Com base no decreto de desapropriação, as agências de Estado impuseram às comunidades tradicionais a condição de "posseiros" $e$ intrusos nas terras que afirmaram

3 O Japão procurava parceiros em países subdesenvolvidos para transferir indústrias minerais que requeriam muita energia elétrica (Lobo, 1996; Monteiro, 2005). 
pertencer ao Estado, visto que seus moradores não possuíam documentos de propriedade.

Essas mesmas práticas de expropriação e deslocamento se produzem atualmente acionadas pelo Estado e pelas empresas. A falta da titularidade dominial das terras tradicionalmente ocupadas é o argumento usado pelos "agentes do desenvolvimento" e na situação de insegurança fundiária das comunidades tradicionais agrava-se a vulnerabilidade dos seus moradores diante das ações violentas articuladas para viabilizar os interesses de commodities minerais e agrícolas, ainda mais reforçadas pelas políticas governamentais de logística para facilitar a exportação de grãos $e$ minérios pelos portos do município.

Barcarena possui um contexto de "desigualdade ambiental", pois os danos decorrentes das práticas poluentes recaem sobre grupos sociais mais vulneráveis, "configurando uma distribuição desigual dos benefícios e malefícios do desenvolvimento econômico" (Acselrad, 2012:165). Os ribeirinhos, extrativistas das comunidades tradicionais e os quilombolas de Barcarena recebem os malefícios da acumulação primitiva das grandes empresas que têm práticas produtivas insustentáveis ao meio ambiente. São despejos de rejeitos da produção do caulim da empresa francesa Imerys Rio Capim Caulim, no rio Dendê e igarapé Curuperé que contamina as águas e o solo das comunidades tradicionais onde se localizou o Distrito Industrial, e os rejeitos do beneficiamento da alumina da Empresa Norks Hydro/Alunorte no rio Murucupi que afetam as comunidades quilombolas. Além dos rejeitos de coque da empresa TECOP que contaminam o ar, inviabilizando a permanência dos moradores de São Miguel. As comunidades imprensadas entre os muros $e$ as bacias de rejeito das fábricas não têm alternativa de reprodução material, com isso, são levadas a configurar novas relações de forças para disputar recursos afim de garantir a sobrevivência nas terras tradicionalmente ocupadas.

O desenvolvimento elabora diversos discursos e versões sobre sua processualidade, reiteradamente apontando vantagens, a exemplo da ênfase em emprego, renda, crescimento, técnicas inovadoras, mobilidade social, sob a suposição de racionalidade 
superior e eficácia. Camurça (2002:168) elabora argumentos sobre o espaço semântico do desenvolvimento; a autora analisa o sistema de relações que estabelece a prática discursiva que dita as regras do jogo: quem pode falar, sobre que ponto de vista, com que autoridade, e de acordo com o critério de especialidade.

Esse discurso instaura-se como ideia hegemônica nas reiteradas políticas e nos projetos e torna-se uma "metáfora que atribuía uma hegemonia global a uma genealogia histórica puramente ocidental, roubando de povos de diferentes culturas a oportunidade de definir as formas de sua vida social" (Esteva, 1992:9).

No decorrer de mais de quarenta anos de instalação do Complexo Industrial de Barcarena seus enunciados são reiterados, atualizados, recriados por uma multiplicidade de agentes revelando significados convergentes, como os de sustentabilidade, participação e justiça.

Os "tradicionais" e os "nativos" de Barcarena, como eles se denominam foram submetidos e subordinados às políticas $e$ planos de desenvolvimento na cidade, "ingressaram" ao mercado de trabalho informal em condições de reprodução social mínima e sem contar com direitos à proteção social. As desigualdades socioculturais (de gênero, étnicas, etárias) conseguem afetar, de forma diferenciada as unidades sociais e comunidades, com elementos comuns na perda de acesso aos recursos naturais $e$ alteração dos modos de fazer e existir. Configura-se o quadro novo de desigualdades econômicas e políticas e discriminações de cor, gênero, etnia e classe.

A perspectiva de gênero aqui priorizada insiste nas diferentes experiências de mulheres, as ações e os movimentos que protagonizam, em cada tempo, suas representações e como elas se singularizam e elaboram tipos de estratégias nas lutas. A entrada na análise está em debater um feminismo da diferença (a partir da categoria gênero $e$ pensando nas mulheres subalternizadas) e um feminismo da igualdade (pela categoria socioeconômica de pertencimento das mulheres igual aos homens, que com elas, foram expropriados das terras e jogados à sorte) 
(Scott, 2001). Em ambos, não se dissocia gênero de classe. Também não estivera, nem está na pauta dos projetos de desenvolvimento o propósito de romper com a desigualdade de classe. Pelo contrário, os processos de empobrecimento $e$ desestruturação das unidades familiares aumentaram as dificuldades para sua reprodução material e social levando-as à condição de "refugiadas do desenvolvimento" (Almeida, 1996), cuja existência na condição de expulsas de suas terras os situa no cerne das disputas com os planos e projetos do Estado e das empresas.

As narrativas das mulheres dos sítios de Barcarena descrevem os momentos de enfrentamento às primeiras ações da política desenvolvimentista e de instalação das empresas mineradoras. Para essas mulheres, não foram criadas vagas nesse novo mercado de trabalho industrial; elas não foram fichadas nas empresas. Os homens tinham expectativa do contrato assalariado, sem nenhuma estabilidade e com salários miseráveis. Nas pesquisas de Moura et alii (1989) sobre as ocupações dos desapropriados e deslocados para o bairro Laranjal, afirmam que havia limitações de emprego aos desapropriados devido a sua não "qualificação". Os desapropriados ocupavam empregos de vigilantes (27\%), serventes (23\%) e de gari $(9,8 \%)$. No caso das mulheres, depois da ocupação "prendas domésticas" que correspondia a $63 \%$, as demais exerciam ocupações de empregadas domésticas, que correspondia a aproximadamente $11 \%$, copeiras, $6 \%$, costureiras $5 \%$ e lavadeiras em $4 \%$.

Nas entrevistas, as mulheres narram a repressão, a vida de exclusão e discriminação quando foram expropriadas e retiradas dos sítios com marido e filhos $e$, inflexivelmente, lhes foi negada a possibilidade de continuidade das atividades da roça e de fabricação da farinha. Muitas viraram empregadas domésticas, diaristas e lavadeiras das famílias dos funcionários das empresas mineradoras. De forma, refletida e defensiva elaboraram reações diante da desigualdade de gênero e da discriminação social agravada pela política desenvolvimentista. 
Entre outras ações dessa ordem desenvolvimentista executadas pelas empresas sobre os povos tradicionais e suas formas de existência estão os discursos sobre emprego e renda, de organização de cooperativas sob seu controle e de formulação de políticas definidas como de responsabilidade social e de parcerias. Ainda, o controle da participação popular para o que estimula o associativismo $^{4}$, o faccionalismo e o esvaziamento de ações coletivas, de forma a implantar os projetos ditos sociais, ecológicos, culturais; e o discurso e a pauta de gênero ${ }^{5}$ e de empoderamento, que igualmente servem à política de marketing das empresas.

O movimento social das mulheres buscou progressivamente construir enunciados e ações específicas em meio a esse processo de exclusão e reação à uniformidade da lógica capitalista. A participação feminina nas ações coletivas foi de essencial importância para o fortalecimento das resistências ao "desenvolvimento imposto" (Maia; Acevedo Marin, 2014).

A dinâmica de mobilizações sociais formou lideranças femininas que atuam em associações, nas mobilizações e nas articulações da última década perante o Ministério Público na luta por suas territorialidades, contra as práticas ambientais das empresas e pelo direito às formas diferenciadas de existência no seio das comunidades tradicionais.

\footnotetext{
4 Palheta (2004) estuda o associativismo em Barcarena e aponta que entre 1984 e 1994 foram fundadas 15 associações; delas, 60\% eram mais próximas das empresas; $20 \%$ do governo local e $13 \%$ dos sindicatos, o que reforça o poder do discurso do diálogo, da parceria e do não confronto direto com a prefeitura e as empresas.

${ }^{5}$ No bairro Laranjal, construído em aberto conflito com as famílias tradicionais do Terreno São Lourenço, foi instalada uma fábrica de costuras para confeccionar os uniformes dos trabalhadores da empresa Albrás/Alunorte e que envolveu um grupo de mulheres (Palheta, 2004).
} 


\section{Resistências das unidades familiares à implantação da política desenvolvimentista em Barcarena}

A estrutura produtiva de Barcarena até 1970 era constituída por unidades rurais eminentemente ribeirinhas (Tourinho, 1991:120). Segundo dados levantados pelo Instituto Brasileiro de Geografia e Estatística (IBGE), nos Censos Agropecuários de 1970/1980, havia propriedades com menos de 10 hectares, o que é confirmado pelas entrevistas feitas com, os deslocados pela CODEBAR, em trabalho de campo. Essas unidades desenvolviam a lavoura temporária e o extrativismo, com base familiar. Havia produção de arroz, cana-de-açúcar, feijão, mandioca, milho, abacate, banana, cacau, coco e laranja. Nas memórias das comunidades tradicionais de Barcarena, denominadas de sitiantes ou ribeirinhas, os rios conformavam os espaços de articulação $e$ de domínio das redes de parentesco.

O Estado realizou uma profunda intervenção no espaço para adaptá-lo às necessidades das indústrias, e procedeu os deslocamentos das comunidades tradicionais para outras áreas. A instalação do novo núcleo urbano da Vila dos Cabanos, a construção do Porto da Vila do Conde, da Eletronorte, do Complexo de Mineração Albrás/Alunorte alteraram a paisagem $e$ as territorialidades específicas das comunidades tradicionais $e$ quilombolas, que tiveram as suas formas de vida e reprodução social completamente desestruturadas, por processos de exclusão, discriminação, imposição violenta do progresso industrial.

Os sitiantes reagiram e resistiram às ações de deslocamentos da CDI e CODEBAR, utilizando de estratégias de permanência e de uso dos territórios e de seus recursos de forma clandestina, mesmo estando sob controle e vigilância do Estado e das empresas. Foram inúmeras as reações dos agentes sociais diante da destruição de suas roças e do avanço dos tratores em seus sítios. As narrativas orais revelam como foi a imposição do progresso $e$ da ordem industrial no município. Dione da Cruz e Souza relata sobre esse momento. 
[...] a CODEBAR tinha mandado queimar a minha casa, fiquei com a roupa do corpo. Eu fui pro mato tirei pau novamente e vim pra cá, fiz outra casa. Ali, a minha era pra lá da rodoviária, a gente ia pro igarapé lá longe. Ela era também de madeira, mas agora era coberta de telha. Tava dormindo com os meus filhos lá de noite, quando eu ouvi uma zuada, quando eu saí vi um trator assim direto na minha casa, eu tirei as crianças e quando ele veio passou direto e levou minha casa, foi que eu fiquei novamente com a roupa do corpo. [...] fui morar no Laranjal. Lá tinha um terreno assim cerrado da frente e eu peguei e disse que ia invadir o terreno: "Não sei de quem é". Peguei e limpei, fiz uma casinha, quando eu vim aqui no Deco, na Taberna, ele disse que a CODEBAR iria mandar derrubar a minha casa. [...] fui buscar meu terçado $e$ amolei bem amoladinho, me sentei lá e fiquei assim mesmo, em cima de um pau. Eu pulei e disse assim: [...] vão derrubar a minha casa ..., derruba logo, mas em riba de mim".

As famílias que moravam em torno do rio Murucupi foram deslocadas para o bairro do Laranjal. A vida nesse bairro era marcada pela escassez de alimentos e os moradores mais velhos afirmavam que no sítio viviam melhor, havia roças, frutas $e$ criações de animais. E desejavam o retorno para os sítios, e assim, mesmo sob a dura vigilância da CODEBAR, os quilombolas de Barcarena organizaram roças e criadouros de animais nas terras que foram expropriadas.

As narrativas dos quilombolas e moradores das comunidades tradicionais de Barcarena expressam seus sentimentos de exclusão diante desse progresso industrial imposto, $e$ afirmam que eles não foram inseridos no mercado de trabalho $e$ ainda hoje encontram dificuldades para conseguir aposentadoria, pois não possuem tempo de serviço no mercado formal. Ainda, foram retirados da definição de trabalhador rural visto que em suas carteiras de trabalho são registrados inúmeros serviços temporários. Aguardam chegar a idade de sua inserção ao Benefício Assistencial ao Idoso. Os empregos oferecidos atualmente continuam sendo temporários, e alguns jovens das 
comunidades são obrigados a sair do município em busca de empregos em outros municípios e estados. Essa situação de insegurança e estabilidade é definida por seu Aldair Pinheiro, da comunidade de Cupuaçu/Boa Vista, com a expressão "ficamos batendo manivela", sem paradeiro e sem emprego.

Diante do agravamento da situação de abandono $e$ exclusão, os moradores locais organizaram mobilizações contra as políticas de deslocamento, e de estratégias de permanência $e$ retorno aos sítios. Entre as primeiras organizações, destaca-se a Associação dos Deslocados pela CODEBAR (ADEBAR), que, em 1987, organizou todos os deslocados pelo desenvolvimento $e$ entrou com uma ação pedindo a revisão das indenizações. A ADEBAR foi formada pelo Padre Primo e as mulheres dos bairros do Laranjal e Nova Vida, e conseguiu envolver 564 pessoas que entraram com processo de ação indenização. A senhora Judite Lemos fazia parte da ADEBAR e fez considerações sobre o processo movido contra a CODEBAR.

Nós temos um processo que tá rolando até hoje lá, com 564 famílias entre Burajuba, Murucupi, Tauá, Cabeceira Grande, São Francisco, Itupanema, Conde, tá rolando até hoje esse processo [...] Esse processo nos juntamos tudinho e fomos em Belém, nós ganhamos em Belém, e eles recorreram pra Brasília, e em Brasília ninguém tinha dinheiro. Aí nós recorremos e a CNBB bancou pra nós o projeto em Brasília, mais de 20 anos. [...] quando foi em 85, a gente ganhou esse projeto em Brasília. Saiu no Diário Oficial, os advogados vieram aqui, reuniram a gente ali na paróquia, pra verificar o projeto todinho, agora só precisava reunir um grupo de contador pra fazer a contagem do dinheiro, da quantia que ia calhar pra cada um, cada família. E eles foram pra lá, acredita que até hoje não apareceram mais?! (Judite Souza Lemos, 1/5/2015, Comunidade Quilombola São Sebastião do Burajuba).

O mapa abaixo representa as comunidades tradicionais que viveram processos de deslocamentos compulsórios. Nos anos 1970-80, foram deslocadas 494 famílias das localidades: Tauá, 
Cabeceira Grande, Murucupi, Ponta Grossa, Conde, Paramajó, Bacuri, Burajuba, Santo Antonio, São Francisco, São José, Guajará, Vila São Francisco, São Joaquim, São Lourenço, Itupanema.

A comunidade quilombola de São Lourenço perdeu parte das terras tradicionalmente ocupadas para a construção do bairro Laranjal. Eles reagiram acionando o Instituto de Terras do Pará (ITERPA) para revalidar o documento de suas terras. Ao longo do rio Murucupi foram deslocadas compulsoriamente as famílias que viviam nos sítios São João, Conceição, Cupuaçu-Boa Vista $e$ Burajuba e parte das terras foi ocupada pela empresa AlbrasAlunorte e pela Vila dos Cabanos. Entretanto, partiu sobretudo de mulheres a retomada das terras em ações silenciosas de continuar colhendo as roças, plantando até o retorno definitivo para construir novas casas e cultivares em pequenas franjas de terra.

Nas narrativas dos quilombolas são referenciados o processo violento de imposição do "desenvolvimento" configurado no conjunto habitacional Laranjal, o momento em que os tratores abriram as quadras e derrubaram as roças dos moradores, que, por sua vez, reagiram ao aumento da extensão do Laranjal $e$ construíram barricadas e receberam os agentes de desenvolvimento com pedras e paus. Como afirma a senhora Adelaide dos Santos.

[...] O que eles fizeram com nós "olha vocês não podem mudar a casa de vocês de um lado pra outro, vocês não têm direito de tirar uma vara aqui no mato". Proibiram nós de tirar vara, de mudar casa. Então pra onde eles queriam colocar nós? Lá pra $\mathrm{CDI}$, pra aí não sei onde. Aí nós metemos o pé e não saía, não saía. A mãe desse aqui, o trator vinha passar por cima da casa dela, ela puxou foi a espingarda do marido dela e a vassoura, ela disse que se o carro passasse lá ela ia mandar meter o terçado no carro. Tá bem aí a rua, aonde ela parou atrás. Até hoje eles não vieram acabar a rua, porque nós não deixamos. 

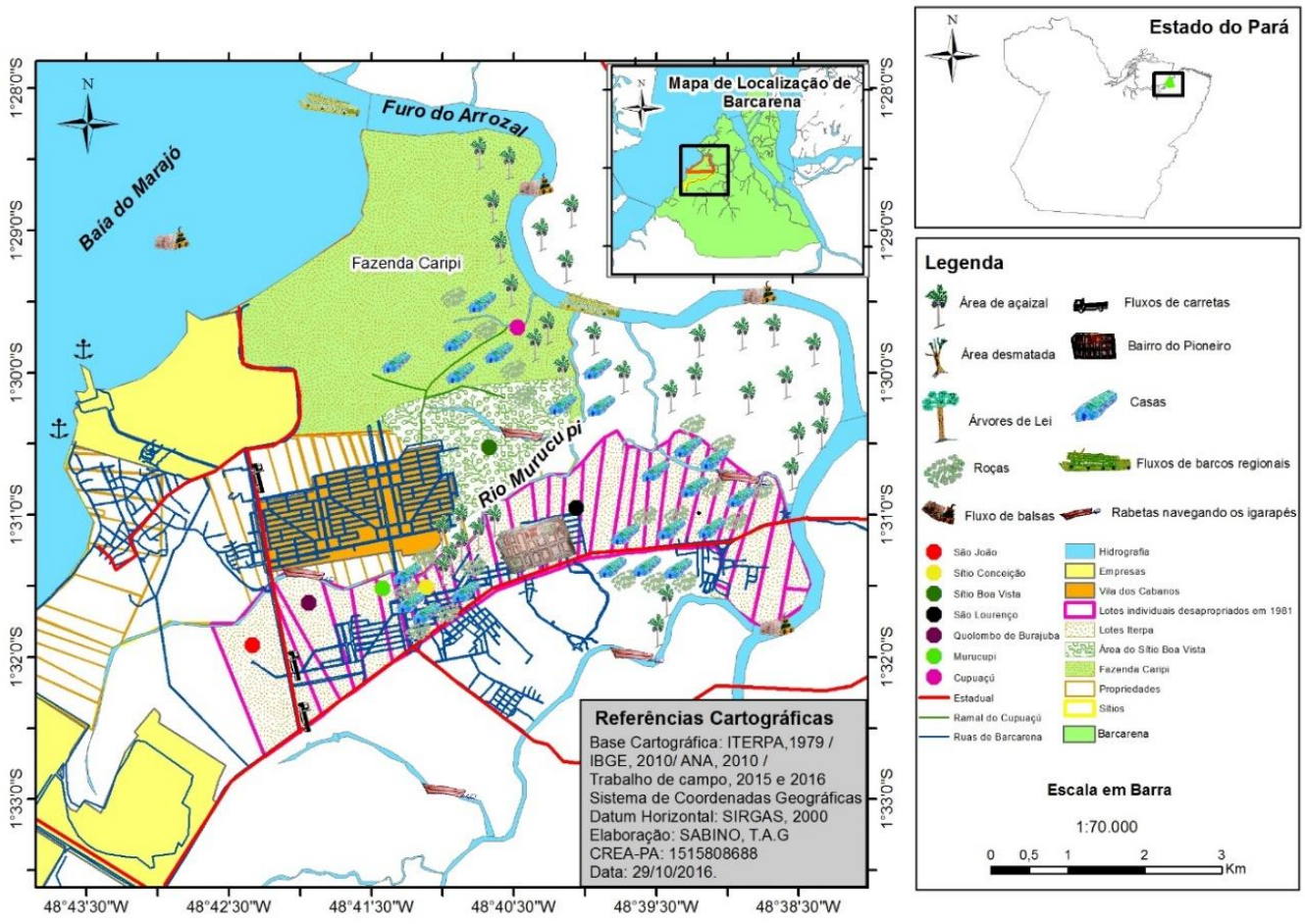

Figura 1. Cartografia social de sítios e comunidades desapropriadas pela CODEBAR (Maia, 2017:145).

O primeiro processo de deslocamento organizado pela CDI ocorreu na década 1980 para implantação da Eletronorte, da Albrás/Alunorte, do Porto da Vila do Conde e da área de proteção ambiental. $\mathrm{Na}$ década de 1990, foram retiradas 11 famílias da Ponta da Montanha, para a construção da empresa Rio Capim Química S/A. Essas famílias foram remanejadas para Curuperé, para a área que eles chamaram de Vila Nova Canaã. À medida que as empresas foram se instalando, a comunidade de Curuperé foi recebendo mais famílias expropriadas ou provenientes de migrações, de sorte que surgiram novas áreas no seu território, a saber: Maricá, Nova Canaã e D. Manoel. 
O local onde essas comunidades estão, hoje, é denominado Distrito Industrial. Após a instalação das fábricas de caulim, foi mais intenso o processo migratório, o que provocou o crescimento populacional no bairro e na Vila do Conde. As comunidades tradicionais ${ }^{6}$ foram atingidas, pois as comunidades do Curuperé, Acuí e Arienga perderam suas partes no território e sofreram agressões ambientais contra os recursos naturais, principalmente nas águas do rio Dendê e Curuperé. Nas narrativas das mulheres de Curuperé e Acuí são ressaltadas as lutas e resistências ao projeto desenvolvimentista nas quais outras práticas, outros discursos e mudanças nas estratégias foram elaboradas.

[...] teve uma coisa boa que aconteceu ali né, que eu vou dizer pra vocês, a coisa boa que aconteceu ali na nossa comunidade é que a gente aprendeu lutar né, a gente não apenas cruzou os braços (Eunicéia Fernandes Rodrigues. Seminário Carajás 30 anos, em 11/4/2014).

Maia (2017) releva os processos de deslocamento realizados pela CODEBAR na década de 1990, diferenciados dos que protagonizou o complexo industrial do caulim da empresa Imerys Rio Capim Caulim e da USIPAR, que se encarregaram diretamente de realizar os processos de negociação e deslocamento. A USIPAR desapropriou 8 famílias na comunidade Arienga e 57 em Acuí. Constam dessa lista nomes de 22 mulheres.

O governo do Estado do Pará, por meio da Companhia de Desenvolvimento Econômico do Pará ${ }^{7}$ (CODEC), continuou

${ }^{6}$ No estudo de Raphael Frederico Acioli Moreira da Silva, analista do MPU/Perícia/Antropologia para a elaboração do Laudo Técnico $n^{\circ}$ 001/2016SEAP, são referenciadas a origem $e$ a identificação como comunidades tradicionais de Curuperé, Acuí, Maricá, ilha de São João, D. Manoel, região do rio Arienga, Pramajó/Peteca, Canaã e Bairro Industrial.

7 O processo de instalação das empresas no Distrito Industrial foi coordenado pela CDI, a qual faz o cálculo da área adquirida a ser vendida à empresa requerente, somente com a anuência da CDI. Esta, por meio da Lei $n^{\circ} 8.098$, de 1 de janeiro de 2015, passou a denominar-se Companhia de Desenvolvimento 
desenvolvendo políticas de incentivos a investimentos para região, disponibilizando às empresas os territórios ocupados pelas comunidades, ainda intermedia as negociações de indenizações $e$ deslocamento das comunidades como Curuperé, Acuí e Arienga. Mas, os processos de retorno, permanência e migratórios têm dificultado as ações desenvolvimentistas da CODEC, que impede a disponibilidade de recursos e territórios às empresas. Ao mesmo tempo, as comunidades tradicionais e quilombolas formaram novas associações e grupos de mobilizações para garantir a permanência e organizar estratégias de retorno ao território. Elas buscam junto ao Ministério Público Federal o reconhecimento pelo direito ao território por meio de suas territorialidades específicas e sua tradicionalidade.

As territorialidades específicas (terras indígenas, terras de quilombos, babaçuais livres, faxinais, fundos de pasto, comunidades ribeirinhas) constituem terras tradicionalmente ocupadas e controladas pelas comunidades ou por suas organizações associativas, sindicatos, cooperativas e movimentos socais (Almeida, 2012). Com suas resistências cotidianas (Scott, 2011; 1986) percebidas com sua permanência nos sítios, nas roças clandestinas e nas mobilizações coletivas impediram as ações de expropriação e exclusão da CDI e CODEBAR, todavia estas continuam recorrentes contra os moradores das comunidades tradicionais. Nesse contexto relacional com os agentes do Estado $e$ das empresas, constroem os discursos ocultos que alimentam sua arte de resistência (Scott, 2004) diante do poder simbólico hegemônico do Estado, provando que desejam outras práticas e modos de vida diferentes das impostas pela lógica do capital.

Econômico do Pará (CODEC), vinculada à Secretaria de Estado de Desenvolvimento Econômico, Mineração e Energia. A CODEC continua atuando perante as comunidades tradicionais para remanejamentos $e$ indenizações das terras da área do Distrito Industrial de Barcarena, buscando, com as indústrias em torno das comunidades ou novas empresas, propostas de investimentos, e a intermediação nos processos de indenização e remanejamento de nove comunidades: D. Manoel, Curuperé, Arienga, Acuí, Maricá, Santa Rosa, Canaã, Bairro Industrial e Peteca. 
Após a imposição das práticas e ações de desenvolvimento, revestidos pelo mito do progresso, o conflito socioambiental em Barcarena se agrava interruptamente até agora. São as mulheres que atuam nas denúncias e manifestações contra as irresponsáveis práticas ambientais das empresas mineradoras e das ações violentas dos agentes do Estado; recorrendo às instituições jurídicas e ambientais exigindo o reconhecimento por seus direitos como comunidades tradicionais; recorrem à pluralidade jurídica nos dispositivos jurídicos contidos na Convenção 169 da OIT. Essas ações representam momentos de intensa mobilização social por direitos em Barcarena.

\section{Lideranças femininas nas lutas por direitos das comunidades tradicionais da Vila do Conde}

A Norsk Hydro (Alunorte e Albrás), a Imerys Rio Capim Caulim, a Pará Pigmentos, a Buritama, a Tecop, a Votorantin e a Usipar continuam atuando para transformar o município de Barcarena em depósito de rejeitos industriais, desmatando florestas e deslocando pessoas para construir mais bacias de rejeitos, com a permissão e o incentivo dos governos local, estadual e federal. Há um interesse institucional de transformar Barcarena no centro logístico/portuário $e$ industrial do nordeste paraense, buscando estratégias de assegurar a acumulação primitiva com base nas commodities minerais e no agronegócio.

As empresas instaladas ampliam o domínio territorial no distrito industrial, construindo fábricas e portos, o que contribui para consolidar o chamado complexo industrial/portuário de exportação de alumínio e caulim. O agronegócio vê nos portos de Barcarena possibilidades da exportação de soja e milho pelo Norte do Brasil, fazendo investimento em portos e logística no município. Usando o potencial hidroviário do Norte do país, a empresa de logística Hidrovias do Brasil investe no município construindo uma estrutura portuária na Vila de Itupanema $e$ 
também organiza o projeto chamado Operação Norte ${ }^{8}$, com a intenção de implantar um corredor logístico norte, para atender à demanda de transporte e escoamento de grãos da região CentroOeste.

As ações de deslocamentos $e$ indenizações usadas pelas empresas $e$ pelas agências de desenvolvimento são constantes $e$ ficam assombrando as famílias e comunidades que estão na expectativa das mudanças provocadas pelo Projeto Norte, que tem a intenção de incluir o município no projeto logístico de exportação. São recorrentes os depoimentos das mulheres que preveem novamente outras rupturas em suas formas de existências. São narrativas em que as elites políticas desconhecem intencionalmente, a presença, a existência $e$ a diferença das territorialidades especificas, os direitos territoriais e os projetos de futuro de outras mulheres e homens.

Sempre ameaçado de sair, sempre ameaçado. Aí agora com essa: tão falando da ferrovia ela tá vindo né, que tinha parado, mas a ferrovia tá vindo. A Dilma assinou dia 14, assinou de novo, já está de novo ela vem. Vem a ferrovia. Pode procurar na internet que ela tá lá. Dia 14 de fevereiro, a Dilma assinou o edital de novo. A ferrovia tá vindo. Quer dizer existe uma possibilidade de ela passar aqui. Aí eu digo: "meu Deus, que não passe pra cá, passe pra lá, que eu não quero que passe aqui". Eu estava falando agora com aquele meu filho: "tomara que não passe no nosso terreno" [...] "Ah, meu filho, eu não quero mais saber disso, a gente já não tem mais aquela idade. A gente já quer sossego sabe, fincar pé, fincar raiz, assim diz o pessoal. Viver uma vida mais sossegada, né?!" (Maria de Fátima Dias dos Anjos, liderança da Comunidade do Curuperé, em 07/3/2014).

8 O projeto envolveu a construção de uma Estação de Transbordo de Cargas (ETC), localizada em Miritituba, e do Terminal de Uso Privado (TUP), localizado em Barcarena [http://hbsa.com.br/a-empresa - acesso em: 23 jan. 2017]. 
Os agentes e os projetos de desenvolvimento ainda são presentes no município, e seus reflexos sociais mostram semelhanças. Assim, quem viveu os anos 80 , de instalação do complexo minerador, conecta com o atual projeto logístico da ferrovia Norte/Sul, dos novos portos e empresas, que anunciam os deslocamento e processam as incertas e duvidosas indenizações. Esse ponto remete à questão de Joan Scott (1995:75): "como o gênero dá sentido à organização e à percepção do conhecimento histórico?" As narrativas que estamos analisando têm um lugar de enunciação: elas ocorrem no espaço público e da política em que as mulheres das comunidades tradicionais de Barcarena atuaram $e$ continuam desenvolvendo ações, envolvidas em sistemas políticos de poder referidos ao Estado $e$ às empresas coadjuvantes nas políticas desenvolvimentistas. Nessa contemporaneidade, a linguagem dos projetos incorporou o discurso da participação nas audiências, de informação com base nos mapas georreferenciados, sem ponderar que outro posicionamento (o de não aceitar) venha a interferir na decisão, que autoriza a construção da ferrovia, já tomada pela presidente do Brasil.

Chegou um cidadão da Hydro lá e ele mostrou um mapa de onde a ferrovia vai passar, daqui com três anos. Vai passar em cima da casa dela, e da casa dela pra minha é 100 metros. Aí o que ele falou, foi assim mesmo: "o povo daqui da ferrovia, uns 100 metros, vai ser indenizado e vai ter que sair daqui". Mas isso são coisas a ser estudado, ainda vai ter audiência pública, sendo que a presidente já autorizou. Ele falou que é daqui a três anos (Sandra Amorim, Presidente da Associação da Comunidade Quilombola Sítio São João, em 31/8/2014.)

O discurso do desenvolvimento continua com enunciados repetitivos que se fundamentam em hierarquias de classe. Maia (2017) entrevistou agentes, técnicos de instituições (CODEBAR, CDI, SPU, SUDAM, ITERPA) que comumente usam a expressão "caboclo" em referência às pessoas de Barcarena. Tal expressão é desqualificadora, os destinam à condição de pobreza e portanto 
"beneficiados" pela intervenção desenvolvimentista. Dessa forma, opera-se o não reconhecimento de que existam comunidades tradicionais; de que possam existir grupos indígenas locais $e$ quilombolas; portanto, opera-se a negação da consciência $e$ autoidentificação social, cultural. Em 2015, foi lavrado o Termo de Compromisso de N. 08/2015 (publicado no Diário Oficial em 15/10 daquele ano) que determina a consulta à população que habita a área do Distrito Industrial no tocante ao remanejamento. $\mathrm{O}$ segundo Termo de Compromisso, para o qual foi elaborado o Laudo técnico $n^{\circ}$ 001/2016-SEAP já citado em nota, faz referência à existência de comunidades tradicionais no município.

Os frequentes e cumulativos danos ambientais provocados pela exploração mineral contaminaram os rios e o solo. Acevedo Marin (2013:85) afirma que "os projetos Mínero-Metalúrgicos instalados em Barcarena são revelados e deparados como antinomia do progresso". Os sucessivos crimes ambientais praticados pelas empresas são reflexo da prática de exploração colonizadora do grande capital aos países dependentes de seus investimentos. Valendo-se da oportunidade das políticas governamentais locais, baseadas no desenvolvimento a qualquer custo, essas empresas se utilizam de estratégias para baratear o custo do processo produtivo, negligenciando os investimentos em planos de contingências para evitar danos ambientais. Tais crimes $e$ danos ambientais dificilmente são reconhecidos e quando ocorrem são identificados como "acidentes", denominação utilizada pelas empresas com base em critérios técnicos e que consta em relatórios, notícias de imprensa e peças jurídicas.

No intervalo entre 2000 a 2016, foram registrados crimes e danos ambientais sucessivos em Barcarena que conduziram a ações jurídicas contra as empresas Imerys Rio Capim Caulim S.A e a empresa Alunorte, adquirida pela empresa norueguesa Norsk Hydro que manifesta posição irreverente diante das ações judiciais envolvendo a sua acionista por crimes ambientais e danos morais. 
Figura 2. Crimes e danos ambientais de 1991 a 2016

\begin{tabular}{|c|c|c|}
\hline Ano & Empresas & Crimes e Danos Ambientais \\
\hline 1991 & ALBRÁS & Responsável por casos de fluorose. \\
\hline 1996 & Rio Capim Caulim & $\begin{array}{l}\text { Retirar a areia da praia da Vila do Conde, para construir o Porto na Ponta da } \\
\text { Montanha. }\end{array}$ \\
\hline 2000 & Balsa Miss Rondônia & Vazamento de óleo na praia de Conde da balsa Miss Rondônia. \\
\hline $\begin{array}{l}\text { Abr. } \\
2003\end{array}$ & Alunorte & Peixes mortos encontrados no rio Murucupi. \\
\hline $\begin{array}{l}\text { Maio } \\
2003\end{array}$ & Alunorte & $\begin{array}{l}\text { Cor da água do Murucupi foi alterada, bacia de contenção de rejeito } \\
\text { transbordou. }\end{array}$ \\
\hline $\begin{array}{l}\text { Jun. } \\
2003\end{array}$ & Alunorte & $\begin{array}{l}\text { Cor da água do rio Pará ficou avermelhada, peixes morreram. Evandro } \\
\text { Chagas apontou presença de produtos alcalinos no tratamento de bauxita. } \\
\text { Ibama concluiu que houve vazamento da bacia de decantação do minério da } \\
\text { Alunorte. }\end{array}$ \\
\hline 2004 & $\begin{array}{l}\text { Imerys Rio Capim } \\
\text { Caulim S. A }\end{array}$ & $\begin{array}{l}\text { Cor da água dos rios Curuperé e Dendê mudou de verde para amarela, } \\
\text { derramamento de rejeitos químicos industriais. }\end{array}$ \\
\hline 2004 & Alunorte & $\begin{array}{l}\text { Chuva de fuligem em Barcarena (combustão lançada na atmosfera na praia e } \\
\text { casas na Vila do Conde. Crianças e adultos tiveram problemas respiratórios. }\end{array}$ \\
\hline 2005 & Alunorte & Vazamento de 80 litros de soda cáustica. \\
\hline 2006 & Imerys & $\begin{array}{l}\text { Contaminação de poços do bairro industrial em decorrência do processo de } \\
\text { beneficiamento do caulim. SECTAM apurou a existência de fissura na bacia } 3 \\
\text { da empresa Imerys. }\end{array}$ \\
\hline $\begin{array}{l}2006 \\
2007\end{array}$ & $\begin{array}{l}\text { Imerys Rio Capim } \\
\text { Caulim S. A }\end{array}$ & $\begin{array}{l}\text { Lançamento excessivo de fuligem das chaminés da Imerys. } \\
\text { Carreamento de efluentes ácidos que atingiu os igarapés Curuperé, Dendê, rio } \\
\text { Pará e as praias do Caripi e Itupanema, desalojou cerca de } 18 \text { famílias em } \\
\text { torno do Igarapé Dendê e Curuperé. }\end{array}$ \\
\hline 2009 & Alunorte & $\begin{array}{l}\text { Carreamento de lama vermelha para o rio Murucupi causou a morte de } \\
\text { centenas de peixes e prejuízos aos moradores em torno do rio. Resultou em } \\
\text { um TAC e processos individuais por danos morais contra a Alunorte. }\end{array}$ \\
\hline 2010 & Imerys & Nuvem de fuligem sobre o bairro industrial \\
\hline 2011 & Imerys & $\begin{array}{l}\text { Rompimento de duto com efluentes ácidos, atingindo os igarapés Curuperé e } \\
\text { Dendé. }\end{array}$ \\
\hline 2012 & Imerys & $\begin{array}{l}\text { Vazamento de caulim por uma fissura na tubulação que transporta polpa de } \\
\text { caulim entre o porto e a planta da empresa, atingindo o igarapé Maricá. }\end{array}$ \\
\hline 2014 & Imerys & $\begin{array}{l}\text { Vazamento de caulim das bacias, foi feito um TAC firmado pelo MPF, MPE } \\
\text { com a empresa Imerys, segundo o qual a empresa ficou com a obrigação de } \\
\text { fornecer cesta básica e } 80 \text { litros de água durante dois anos para } 90 \text { familias. }\end{array}$ \\
\hline 2015 & $\begin{array}{l}\text { Haidar, Minerva } \\
\text { S/A, Global Agência } \\
\text { Marítima, Norte } \\
\text { Trading Operadora } \\
\text { Portuária/CDP }\end{array}$ & $\begin{array}{l}\text { O navio cargueiro Haidar, que transportava } 5.000 \text { bois, tombou e afundou no } \\
\text { cais do porto de Vila do Conde. } \\
\text { Vazamento de óleo no Rio Pará, chegando ao município de Abaetetuba. Toda } \\
\text { a população de Barcarena foi atingida. } \\
\text { Foram distribuídas cestas básicas e água mineral à população. } \\
\text { A operação de cargas vivas foi proibida. Um plano de contingenciamento foi } \\
\text { solicitado pela Secretaria de Meio Ambiente para normalizar as operações do } \\
\text { porto. } \\
\text { O MPF entrou com ações civis públicas contra as empresas. As negociações de } \\
\text { indenizações estão paralisadas. }\end{array}$ \\
\hline 2016 & $\begin{array}{l}\text { Imerys Rio Capim } \\
\text { Caulim }\end{array}$ & Vazamento de caulim nos igarapés Curuperé, Dendê e São João. \\
\hline
\end{tabular}

Fonte: Maia (2017:236). 
$\mathrm{O}$ vazamento na bacia de rejeitos $\mathrm{n}^{\circ} 3$ da Imerys Rio Capim Caulim, ocorrido em 2007, provocou o derramamento de rejeito de caulim no rio Curuperé e Dendê, atingindo o rio Pará. Foram $200 \mathrm{mil} \mathrm{m}^{3}$ de caulim que atingiram $19 \mathrm{~km}$ de extensão, o que comprometeu os poços dos moradores; e o risco de rompimento da barragem de rejeito provocou o remanejamento de famílias da Ilha São João e Curuperé. Esse acidente gerou uma ação do Ministério Público do Estado do Pará, que resultou no Termo de Compromisso de Ajustamento de Conduta. ${ }^{9}$

De que forma relacionar as lutas cotidianas narradas pelas lideranças femininas com necessidades expressamente agravadas pelos crimes ambientais, sem desconsiderar as "construções culturais - a criação inteiramente social sobre os papeis adequados aos homens e às mulheres" (Scott, 1995:75). Abordamos os reiterados crimes ambientais provocados pelas empresas como forma de poder, como uma prerrogativa do crescimento da produção sem consideração de risco social $e$ ambiental e que podem ser negados e contestados por agentes empresariais em situações de judicialização. Mulheres e homens comungam da crítica às empresas e de acusação de arbítrio, prepotência e descaso. As observações da senhora Rosicléia Cabral Araújo, da comunidade do Curuperé, em entrevista no dia 07/03/2014, mostram a pressão e a negociação para que a empresa assuma responsabilidade pelos danos ambientais.

\footnotetext{
9 Ministério Público do Estado do Pará. Promotoria de Justiça de Barcarena-PA. Termo de Compromisso de Ajustamento de Conduta. Procedimento $\mathrm{n}^{\circ}$ 001/2007-MP/1 ${ }^{a}$ PJB. Barcarena/Belém. 30/11/2007. Nas considerações do documento é feita menção ao dano ambiental decorrente do acidente causado pelo vazamento de 300.000 metros cúbicos de rejeitos nos igarapés Curuperé, Dendê, rio Para, Praias de Conde, Caripi e Itupanema e da pista de rolamento o Bairro Industrial.

[https://www2.mppa.mp.br/sistemas/gcsubsites/upload/41/TAC\%20IMERYS\%202 007\%20-\%20BARCARENA.pdf - acesso em: 25 maio 2018].
} 
[...] a dificuldade maior mesmo aqui é o problema da energia porque, e a água também né, a gente tinha os nossos poços que era a coisa mais linda [...]

É a Imerys. Pela Imerys é aquele tatuzão, porque na época que eles poluíram os nossos poços, que deu caulim nos nossos poços, o Evandro Chagas veio aí e constatou que tava tudo poluído. A gente tinha que é, desativar os poço, aí foi ordem judicial que eles tinham que trazer água potável pra nós [...]

[...] Você olha aqui, você vem de noite tem energia, a bacia quatro da empresa é bem aqui, olha. Tá bem aí no poste a energia, aqui a bacia cinco e seis da empresa tá bem; aqui a gente fica morando aqui ao redor da, das bacias e a gente corre um risco muito grande aqui nessa época de inverno, que essas bacias...

Diante dos sucessivos crimes ambientais praticados pelas empresas, as comunidades do Distrito Industrial iniciam uma luta para o remanejamento de seus moradores para espaços distantes das bacias de rejeitos. Em 2010, solicitaram do Governo do Estado do Pará medidas para acabar com a situação de insegurança ambiental e fundiária vivenciada pelas comunidades. Por meio de suas associações, exigem audiências públicas para colocar em debate a questão ambiental e políticas de remanejamento consideradas mais justas e adequadas para as comunidades.

Em entrevista, a senhora Cleide Monteiro, da comunidade do Acuí, uma das principais lideranças que atuaram nesse processo da luta, afirma que estavam usando de uma estratégia inovadora quando requereram em audiência a participação do Governo do Estado do Pará, da CDI, ITERPA, MPE, INCRA e empresas para discussão sobre o remanejamento da população do Distrito Industrial.

[...] só que essa conquista que nós tivemos, de poder sentar na mesa essas três esfera, né, sociedade, a empresa e o governo, foi uma conquista muito grande, porque há trinta anos esse ping pong: quando a gente ia lá com o governo ele dizia: "negativo quem tá contaminando vocês é a 


\begin{abstract}
empresa"; quando a gente ia com a empresa ela dizia: "é o governo que deve pra vocês, porque nós pagamos os nossos imposto". Então quem ficava com o prejuízo era a sociedade. Então quando a gente acionou e forçou né, a todo mundo sentar na mesa, hoje nós temo todos os personagens na mesa [...] (Cleide Góes, liderança da Comunidade do Acuí e representante das comunidades tradicionais de Conde e Distrito Industrial no GT que trata sobre remanejamento das comunidades).
\end{abstract}

Na audiência pública de 28 de junho de 2010, houve a formação de grupo de trabalho, reconhecido e empossado pelo Governo do Estado por meio do decreto de 22 de Julho de 2010, publicado em Diário Oficial em 23 de julho de 2010. O GT teria a participação de três representantes das comunidades da área objeto de intervenção das empresas e da CDI com a representação de uma líder comunitária. $\mathrm{O}$ grupo de mulheres das comunidades tradicionais insere-se nas lutas e continua exigindo das instituições públicas e das empresas o reconhecimento de seus direitos; também percebe que suas mobilizações e organizações devem ser mais articuladas. Entre as lideranças, há um sentimento de resistência ao projeto de desenvolvimento.

Agora nós vamos sentar e eu quero saber quantos milhões vocês vão investir aqui na área social. Eu quero saber do governo, eu quero saber do município e nós vamos ter que trabalhar em conjunto pra ter um novo modelo de desenvolvimento em Barcarena. [...] hoje nós estamos organizados e o que que falta hoje, será que ela ainda vai continuar resistindo, então nós sociedade, nós estamos mostrando que nós não somos contra elas porque se não nós não fazia todo esse levantamento que a gente tá fazendo. Porém se tem resistência do lado dela, aí a população com o esclarecimento que tem, como munícipes que nós somos, nós vamos ter que reagir de forma mais pesada ou ela vai se adequar ou ela vai ter que sair daqui. Dessa vez, quem vai ter que sair é ela (Cleide Monteiro, Associação dos Moradores da Comunidade do Acuí. Entrevista realizada em 05/5/2013). 
[...] então a estratégia é para diminuir a resistência porque toda estratégia para o avanço desse progresso só visa duas coisas, diminuir a resistência e diminuir os recursos porque há custos pra desapropriar e para resistir e a maior resistência há maior custo então vamos tentar minimizar a resistência, fazer negociação individual. [...] então se não podemos assegurar os direitos que são violados quando alguém é desapropriado, se essa desapropriação fazem parte do pacote que vem para o desenvolvimento eu pergunto esse desenvolvimento é pra que? [...] até hoje nós continuamos vivendo nas favelas, nas desgraças que as empresas trazem ninguém eu confesso pra vocês que ninguém toma nossas dores nesse município e até quando a gente faz reunião que nós vamos até eles, eles nos menosprezam nossos documentos dizendo que nós não somos nativos; nós não somos povos tradicionais desse lugar , $e$ que nós não temos direitos é incrivel como sua mentalidade ainda permanece a mesma o mundo mudou, o tempo mudou os anos se passaram muitas pessoas da comunidade já tem um conhecimento maior, mas não somos olhados do mesmo jeito que nós fomos olhados antigamente (Eunicéia Fernandes Rodrigues, em 05/5/2016. Liderança da comunidade do Curuperé).

As discussões sobre o remanejamento das comunidades do Distrito Industrial prosseguem até o presente. A população experimenta cotidianamente as pressões da empresa $e$ as tentativas de cooptação das instituições que querem individualizar a discussão e a negociação do remanejamento, não reconhecendo a legitimidade do GT no que se refere à participação dos eleitos pela comunidade para coordenar os processos $e$ defender os interesses coletivos das comunidades. Utilizando estratégias políticas e econômicas, buscam enfraquecer a mobilização das comunidades tradicionais do Distrito Industrial.

Apontamos aqui a relevância frisada por Joan Scott (1995:88) de precisar a análise das instituições e a organização no estudo das relações de gênero. Nessa perspectiva, "gênero é uma 
forma primária de dar significado às relações de poder, um campo primário no interior do qual, ou por meio do qual, o poder é articulado".

A situacionalidade espaço $e$ tempo para debater gênero $e$ poder também é ressaltada por Brah (2006:341) em sua afirmação:

Nosso gênero é constituído e representado de maneira diferente segundo nossa localização dentro de relações globais de poder. Nossa inserção nessas relações de poder se realiza através de uma miríade de processos econômicos, políticos e ideológicos.

Essas afirmações da autora reforçam a construção da percepção não unitária da categoria mulher, cuja compressão está condicionada à sua condição social específica, o que apoia a necessária descrição das particularidades, especificidades $e$ diversidades sociais em que estão inseridas as mulheres das comunidades tradicionais de Barcarena.

\section{Luta das mulheres pelo reconhecimento de direitos territoriais em torno do rio Murucupi}

O núcleo urbano planejado pela CODEBAR não se constitui em projeto bem sucedido. A cidade moderna e aberta constitui-se em um espaço em disputa e de conflito entre as empresas, a prefeitura, os migrantes $e$ os antigos moradores que foram expulsos de seus sítios. Os planos de formar a cidade aberta $e$ moderna foram afetados, pois o projeto de urbanização desenhado para dar suporte ao complexo de mineração tornou-se inviável devido à falta de recursos da empresa estatal e das incongruências do projeto desenvolvimentista, cuja meta principal afeta os modos de vida das comunidades locais, disponibilizando suas terras e recursos ao grande capital, deixando sequelas sociais $e$ culturais nessas comunidades, sem proporcionar outras alternativas de modo de vida. Portanto, sem concluir o sonhado projeto urbano que se consolidaria com a cidade aberta $e$ 
planejada, a CODEBAR entrou em processo de liquidação em 2008.

O patrimônio imobiliário da empresa deveria gerar recursos financeiros, portanto os liquidantes iniciaram o processo de venda e leilões dos lotes e quadras do núcleo urbano que anteriormente eram ocupados pelos sitiantes em torno do rio Murucupi. Nesse momento, a situação de conflito por territorialidades foi reaquecida, visto que as comunidades que insistentemente permaneceram nos sítios estavam novamente sendo ameaçadas de serem expulsas do território. $\mathrm{E}$ os moradores dos sítios que foram deslocados para $\mathrm{o}$ Laranjal e outras localidades, perceberam que esse era o melhor momento de organização de estratégias de retorno aos sítios. $\mathrm{O}$ processo de retorno foi liderado e planejado pelas mulheres das comunidades tradicionais.

Era o sonho da minha mãe. Quando ela viu essa área desocupada, era o sonho dela voltar pra cá, ela pedia pra um e pra outro ajudar, como faria pra voltar pra essas terras. [...] Mas, mesmo assim, ela nunca perdeu a esperança, nunca perdeu. Quando ela via esse pedaço aqui, ela passava e brigava com esse pessoal que já tinha casa aqui; ela discutia com esse pessoal que tinham comprado da CODEBAR, a terra. Aqui essa parte dessas lojas, das empresas aí, aí foi acima e foi abaixo e ela adoeceu; e quando ela esteve lá em Belém comigo, ela dizendo. A última vez que ela esteve lá em Belém comigo disse: "minha filha, a gente tem que voltar para as terras. Tô vendo lá o que a gente pode fazer, quem pode ajudar, a gente entrar lá na marra mesmo e ver o que é que acontece. Convida teus irmão e vão pra lá" [...] (Vera Lúcia Cravo, 14/7/2014, Comunidade Quilombola Sitio Conceição).

Mas eu sempre tive um sonho de voltar para aquelas terras sempre a vontade de voltar para as terras [...] Então quando passava o ônibus na frente, eu via as castanheiras né. Lembrava, vinha na mente aquelas coisas que a gente fazia lá, brincadeira, e ai um dia vou voltar. Aí começou o pessoal a voltar para as terras, aí eu disse: "então chegou a 
hora, né". Aí voltei, voltei para terra. Primeiro voltou eu e meu irmão, depois fomos chamando o restante né, os outros irmãos, eles vieram. Quem voltou primeiro foi eu com Zé, que voltamos para terra; depois, logo em seguida, veio a Catarina, Nazaré, o Germano (Sandra Amorim, 31/8/2014. Comunidade Quilombola do Sitio São João).

Fez uma barraca de plástico, vamos morar. Isso já tinha quatro dias, nós tudo calado, fazendo calado. Polícia chegou, mas muito carro e mais a Codebar, mas o Hilário: "tem um papel pra sair da terra, baseado em que?". "O juiz de Barcarena assinou, porque a Codebar que tem a posse da terra". "Eu quero ver o documento, é muito fácil tu dizer que tem a posse. Isso aqui é da União" [...]. A polícia veio e jogou spray na minha cara, outro me empurrou. Bem, resumindo, eu falei só comigo "ei a onda vai aumentar". Fui lá em Barcarena, emprestei a cartucheira do cara lá, "quem tem terçado, então bota o terçado na mão" e eu com a cartucheira. Foram embora buscar mais reforço da delegacia, aí sabe o que eles fizeram? Eles mandaram os caras que eles tinham vendido o terreno vim aqui. Aí chegou o dono da Fiat (Maria do Socorro Costa da Silva, em 28/8/2015. Comunidade Quilombola São Sebastião do Burajuba).

$\mathrm{O}$ embate entre a CODEBAR $e$ as comunidades tradicionais ficou mais intenso, porque os moradores interditaram ruas, impediram a ação da polícia, organizaram manifestações na CODEBAR/Belém. Os moradores da comunidade do Boa Vista e Burajuba enfrentaram a CODEBAR e lutaram por suas formas de existência, acionando o MPF para mover ações ${ }^{10}$ a fim de impedir os leilões feitos pela empresa e garantir a permanência no território. Com base na Convenção 169 da OIT, não poderiam ser retirados dos seus territórios, por suas peculiaridades comunitárias tradicionais.

${ }^{10}$ Processo n ${ }^{\circ} 2007.39 .00 .000159-9$ e Processo nº 2008.39.00.004422-8. 
(P.: O leilão era aqui mesmo?) Era aqui no Cabana Clube. Aí, nós na frente, falamos lá. O seu Petrolino que também foi uma pessoa que nos ajudou, ele era um líder sindicalista, também junto com o senador que ele trabalha com ele lá, aí ele tava lá na frente; nós falando tudo. Eu cheguei com a minha liminar que tinha chego. O doutor Felício me ligou: "Olha, Silva a liminar saiu" Já tava tudo lá na frente, aí eu cheguei com a liminar, nós imprimimos ela e fomos tudo pra cima dele. Aí eles pegaram a liminar, olharam e ligaram pro Ministério Público: "olha o resto vocês podem até mexer, mas a área do Boa Vista vocês não podem vender um metro (Maria da Rosa Silva. Presidente da Associação da Comunidade do Boa Vista, em 26/8/ 2015).

As resistências das comunidades tradicionais não foram aceitas como autênticas pelos gestores da CODEBAR e da elite local. Com o crescimento do debate sobre comunidade tradicional, quilombola e quilombola indígena, a CODEBAR utilizou o discurso de que as pessoas estavam sendo manipuladas por lideranças políticas e eram oportunistas e invasores. Esse discurso hegemônico está sendo ameaçado com o aprimoramento das ofensivas das comunidades tradicionais às tentativas de desarticulação organizada pelas empresas e poderosos locais.

Em 2010, os imóveis remanescentes da CODEBAR foram transferidos à Superintendência do Patrimônio da União ${ }^{11}$, quando as disputas territoriais com as comunidades locais se tornaram mais acirradas. Houve assim o endurecimento nas relações referentes aos processos de legitimidade dominial dos territórios tradicionais, visto que na visão dos gestores da instituição os quilombolas indígenas são invasores e impostores.

Esses chamados "invasores", por meio de uma política identitária com base em critérios de identidade quilombola $e$ quilombola indígena, tradição impuseram ao campo jurídico o reconhecimento do direito ao território e o respeito da pluralidade

\footnotetext{
${ }^{11}$ Mediante Portaria $n^{\circ}$ 015, de 08/7/2010, o Ministério do Planejamento, Orçamento e Gestão regulamentou a Comissão de Gerenciamento do Patrimônio Imobiliário, oriunda da extinta CODEBAR.
} 
étnica e cultural. O campo jurídico reconheceu que em Barcarena os dispositivos jurídicos deveriam estar baseados pelo princípio da pluralidade do direito, sintonizada com uma "nova sensibilidade jurídica" que se vem desenhando nas últimas décadas no Brasil. É isso que constitui o reconhecimento jurídico dos grupos sociais portadores de identidades étnicas. As comunidades tradicionais de Barcarena constituem unidades de mobilizações (Almeida, 2008:32) com base em suas identidades coletivas; enfrentaram a ordem do progresso industrial; construíram uma estratégia de resistência e de fortalecimento político diante das disputas por recursos $e$ propriedade da terra.

Diante do impasse do reconhecimento pelo INCRA, a comunidade entendeu que suas territorialidades seriam respeitadas com a autodefinição como quilombola. A comunidade do Burajuba se mobilizou pela sua identificação como quilombola, recebendo a Certidão de Autodefinição de Remanescente Quilombola da Comunidade São Sebastião de Burajuba, por meio de portaria em 20 de dezembro de 2013, publicada no Diário Oficial da União $\mathrm{n}^{\circ} 248$, em 23 de dezembro de 2013. A certidão representa uma grande vitória diante desses processos de conflitos.

As comunidades de Conceição, Sítio São João, São Lourenço e Cupuaçu realizaram a autodefinição como quilombolas indígenas em reunião em 31 de maio de 2014 e interpretam a sua política identitária. No curso sobre a Convenção 169 realizado em 31 de agosto de 2014 a questão da autoidentificação tornou-se um debate, no qual Maria do Carmo Freitas falou em nome de um sujeito coletivo:

Somos remanescentes de quilombolas, dos povos indígenas, e nós temos esses direitos aqui. [...] a gente estudando passa a ter um outro conhecimento $e$ vê que não é dessa forma. Hoje muita gente ainda tem vergonha de dizer isso. Eu me orgulho de dizer que eu sou descendente de africano, que meu avô era um negro alforriado, que foi escravo e tudo mais; já a minha avó, eu não tenho muito a história dela, minha tataravó, que era esposa dele, que era filha de português e tudo mais. Tem toda uma história em 
torno disso. Então, minha mãe me dizia que nós somos índios, e outro dizia que nós somos descendentes de negros e acabou gerando essa confusão (Maria do Carmo Freitas, em 31/8/2014, Comunidade Quilombola Gibrié de São Lourenço).

Os processos de Ação Civil Pública movidos pelo MPF contra a União pelo reconhecimento às territorialidades do sítio São João ${ }^{12}$, Sítio Conceição e Sítio Ramal Cupuaçu por sua autodefinição quilombola indígena foram baseados nos Relatórios Antropológicos (Acevedo Marin; Maia, 2013, 2014, 2015) também encaminhados à Fundação Cultural Palmares (FCP) com a solicitação para o reconhecimento da autodefinição quilombola indígena. A demora de mais de dois anos de espera pela Certidão da FCP provocou nas comunidades um clima de desesperança. As comunidades foram coagidas a retirar a denominação quilombola indígena nas documentações apresentadas àquela fundação, pois, segundo as informações, esse era motivo da demora. Eles deveriam fazer um breve relatório afirmando a identidade negra (quilombola) e reafirmando o desejo de certificação de sua autoidentificação. Por conta de uma falta de concepção da pluralidade étnica, marcante na formação da sociedade brasileira, a FCP impõe critérios de identificação étnica. Entretanto, as identidades coletivas não devem se dissolver por mecanismos burocráticos e administrativos homogêneos. A FCP está exercendo o papel de atestador de identidade pura, afirma Maia (2017).

Somente em 18 de novembro de 2016, foi organizado o evento da entrega da certidão de autodefinição quilombola. Autoridades governamentais $e$ institucionais do município foram convidadas para oportunizar aos quilombolas indígenas o reconhecimento de sua existência no município, e assim deixarem de ser propositalmente invisíveis diante dos gestores públicos e lideranças políticas locais. O objetivo do evento, exposto no convite, representava um desabafo e um desafio.

${ }^{12}$ Processo $\mathrm{n}^{\circ} \quad$ 0005977-20.2015.4.01.3900, Processo $\mathrm{n}^{\circ} \quad$ 710223.2015.4.013900 e 3445-73.2015.4.01.3900 
A certificação da FCP representa o início de uma fase mais concreta de luta por direitos étnicos e territoriais no município modelo de instalação do Complexo de Mineração do Estado do Pará. O contexto de conflito ambiental ainda se estende pelo município, $e$ as comunidades tradicionais ainda estão vivendo a insegurança fundiária $e$ a margem das políticas desenvolvimentistas do Estado e do Plano Diretor da Cidade de Barcarena que não os reconhece como sujeitos de direitos de terra e moradia.

As inoperâncias do INCRA $e$ as mudanças institucionais provocadas pelo governo federal têm inibido os avanços das políticas específicas às comunidades tradicionais, principalmente aquelas ligadas à propriedade coletiva da terra $e$ ao uso de recursos que estão em disputa com o agronegócio $e$ às commodities minerais.

A sequência de eventos circunscreve a política, que entendemos, situa as mulheres e o gênero no município escolhido pelo Estado $e$ as empresas para executar uma política desenvolvimentista altamente devastadora. No Plano Diretor do Município é inserido um capítulo sobre "gênero" contendo a descrição quantitativa e frases na "litania" classe, gênero, raça.

No que se refere ao Gênero do total de extremamente pobres no município, 6.832 são mulheres $(48,9 \%)$ e 7.144 são homens $(51,1 \%)$. Em relação a Cor ou Raça do total da população em extrema pobreza do município, 2.124 $(15,2 \%)$ se classificaram como brancos e 11.781 (84,3\%) como negros. Dentre estes últimos, 732 (5,2\%) se declararam pretos e $11.049(79,1 \%)$ pardos. Outras 71 pessoas $(0,5 \%)$ se declararam amarelos ou indígenas. (Prefeitura Municipal de Barcarena, Lei Municipal No 220/2017, de 26 de dezembro de 2017:33).

A abordagem descritiva deste artigo procede de uma opção expositiva e contextual na qual referenciais empíricos são expostos e busca-se mostrar os limites dos estudos e das nossas próprias reflexões. Conseguimos nos alinhar ao debate da política na qual 
o gênero pode ser utilizado, como escreve Joan Scott (1995, 2001), e que permitem fazer reflexões sobre a política ao feminino das mulheres dos povos e comunidades tradicionais de Barcarena.

\section{Considerações finais}

Ao longo deste artigo são ressaltados pensamentos, ações e estratégias de grupos de mulheres em contexto específico de relacionamento com decisões, práticas e discursos sobre o desenvolvimento, ditado por uma política governamental $e$ empresarial que imprime decisóes autoritárias e designa agentes específicos para sua execução, isto é de uma ordem técnica, administrativa, econômica, assistencial, jurídica, policial para produzir remanejamento, realocação, expulsão, repressão, convencimento, desmobilização. É preciso rever ainda como os homens (engenheiros, trabalhadores uniformizados com capacete, botas e sapatos) impressionaram com suas falas estranhas, corpos, gestos $e$ ações as mulheres $e$ homens das comunidades. A narrativa do Sr. Aldair Pinheiro das relações sociais com os estranhos é de choque e a fala de Maria do Socorro Costa da Silva, de raiva e rebeldia.

Aí, chegou um micro-ônibus com uns americanos grandão assim, uns camaradas grandão assim. A gente não entendia nada que eles falavam. Eles chegaram no alojamento da Nortop de manhã pra pedir dois homens pra ir com eles; aí o encarregado tirou dois camaradas e eles não quiseram ir, levantou eu, meu irmão e um primo meu, três, empurraram nós, e não entendíamos nada que eles falavam. Nós fomos, nós falava, eles achavam graça, eles falavam e nós também não sabia o que eles estavam falando e tiravam retrato da gente lá e boto lá no meio do campo. Tava tudo compactado, bonito, botaram lá o aparelho lá, umas malas grande assim de madeira, era cheio daqueles pedaços assim, de um metro de ferro, tudo cheio de vidro assim pintado e muito fio elétrico. Mandaram nós espichar pra todo lado, uma hora pra dentro do mano, lá não tinha marreta, fincava e ficava uma pontinha de fora. Quando 
nós acabamos de fazer essa instalação todinha, ele mandou nós entrarmos pra dentro do ônibus. Aí ficaram lá fora $e$ dispararam um negócio, tipo uma bomba, pra estudar a pressão do solo pra ver se aguentava, se tinha capacidade de receber o que tá lá hoje sab. E nós trabalhemos com esse pessoal um mês. A gente ia almoçar e só tinha um alojamento pro pessoal das empresas almoçar em São Francisco. Aí quando chegava lá pra almoçar, eles carregavam, parece gostava de brincar com a gente. Eram uns monstro de uns peãozão né; carregavam a gente no refeitório, e o pessoal achavam graça, parece criança no braço dos cara, tiravam um retrato nosso, que achavam que nós era índio sabe, levar retrato pra lá pra mostrar pra eles, pro pessoal de lá, como é que era o índio aqui no Pará. Tinha coisa que dava pra gente entender um pouco, com o tempo uns 15 dias que nós tava com eles já ia alejando sabe e eles morriam de achar graça quando a gente se acertava alguma palavra que eles falavam.

O "encontro com o desenvolvimento" nas palavras de Maria do Socorro Costa da Silva, liderança da comunidade quilombola de Burajuba, aponta outro senso interno, desde a posição de mulher, e permite reflexionar socialmente como se constroem as relações de gênero, etnia e classe.

[...] E lá onde nós tava lá e lá vinha uma voadeira. E eu digo pra vocês que muita gente ali, na época, que era uma casa uma distante da outra, não é como é hoje, muito distante. E eles ficaram assustados e eu também. Eu fiquei assustada porque eles me assustaram. Não que eu tive medo. Lá vem uma voadeira. Encostaram lá e lá saíram com um monte de breguesos, umas coisas tipo essas de três pernas (indica o tripé da máquina de filmar) saía também. E uns homens lá com sapato bonito, e eles perguntaram: "Aqui é a praia do Caripi?". É, mas se tu for aqui pela beira, tu chega lá. E meu tio abaixou a cabeça e falou: "isso não é bom". [...] Com um mês depois, lá no São Francisco desembarcou um barco que veio alugado de Belém. Lá desceu outra turma e por lá, eu vi o progresso entrando das 
suas maneiras imundas de fazer. Mas pra mim era uma coisa diferente. Eu nunca tinha visto roupa de seda, eu nunca tinha visto sapato de couro e nem homem bonito. Nesse dia, eu vi; os relógios bonitos. Entraram lá. Pouco tempo foi máquina, e hoje tá aí, a cidade toda esquartejada e a área rural. [...] Me lembro que eu tava lá e chegou um homem bonito e eu era uma menina bonita, tinha umas pernonas[...]. Mas eu me lembro que este homem chegou lá e perguntou pro meu tio quem era eu, ele disse: "essa é minha sobrinha". Então dali entanto, ele começou a investir tanto no meu tio, olha ele chamou meu tio, deu dinheiro, deu uma mala de dinheiro pro meu tio e nós fomos pra Igarapé Miri e Abaetetuba, de barco. Dali que eu vi que começou o interesse, por exemplo, quando eu ia pra escola, ele me dava caderno, quando eu ia pra tal lugar era roupa, quando ele viajava pra essa cidade grande que ele vinha, trazia relógio, umas saia linda pinçada com uns saltinhos. Eu nunca tinha vestido, mas dali eu vi que eu comecei ser a propriedade dele [...] o meu tio cedeu e de lá depois parece que o meu tio fez isso mercado de negócio, que o meu tio mandou buscar mais duas do Icaraú pra ajudar minha tia lavar roupa de peão de lá. A gente lavava lençol, dobrava, passava, entregava, e lá a casa do meu tio ficava assim ó, cheia de macho. Meu tio parece que fazia de sacanagem, se trancava no quarto e deixava nós lá, e assim foi nossa vida [...].

Este artigo deliberadamente assume a hierarquia de vozes femininas, com conteúdo diferenciados pelas experiências de dominação e subjugação, sem reduzi-las à posição de vítimas. Elas reagiram e continuam a mostrar posicionamentos face à reviravolta nas existências individuais e coletivas provocadas pelos projetos de desenvolvimento para seu local, para Amazônia.

\section{Referências bibliográficas}

ACEVEDO MARIN, Rosa Elizabeth. Quilombolas de Burajuba: lutas identitárias e territoriais. Relatório Antropológico da Comunidade Quilombola de Burajuba. UNAMAZ, UFPA, Belém, 2013. 
; MAIA, Rosane de Oliveira Martins. Quilombolas indígenas no sítio São João: formas de resistência no rio Murucupi-Barcarena. Belém, PNCSA, UFPA, NAEA, 2013.

- Territorialidades Específicas dos Quilombolas Indígenas do Sitio Cupuaçu/Boa Vista. Belém, PNCSA, UFPA, NAEA. 2014.

- Quilombolas Indígenas do Sítio Conceição Reivindicaçóes Identitárias e Territoriais. Barcarena-PA. Belém, PNCSA, UFPA, NAEA. 2015.

- Terra tradicionalmente ocupada de São Lourenço: direitos de descendentes de indígenas Gibrié e de Manoel Joaquim dos Santos. Barcarena-PA. Belém, PNCSA, UFPA, NAEA, 2015.

Acevedo Marin, Rosa Elizabeth; Acevedo, Ruben Bentes de Oliveira. Danos sociais e ambientais pela exploração mineral em Barcarena. In: ACEVedo Marin, Rosa; NovaES, Jurandir (org.). Povos tradicionais em colisão com estratégias empresariais no Maranhão e Pará. Manaus, UEA Edições, 2015, pp.139-173.

ACSELRAD, Henri et alii. Desigualdade ambiental e acumulação por espoliação: o que está em jogo na questão ambiental? E-cadernos CES, vol.17, 2012, pp.164-183.

AlmEIDA, Alfredo Wagner Berno de. Os deslocamentos compulsórios de índios e camponeses e a ideologia do desenvolvimento. Energia na Amazônia - Volume II. Museu Paraense Emílio Goeldi. Universidade Federal do Pará, Associação de Universidades Amazônicas, 1996, pp.30-35.

. Terras de quilombos, terras indígenas, "babaçuais livres", "castanhais do povo", faxinais e fundos de pasto: terras tradicionalmente ocupadas. 2.ed. Manaus, PGSCA-UFAM, 2008.

. Territórios e territorialidades específicas na Amazônia: entre a "proteção" e o "protecionismo". Caderno CRH, vol. 25, n 64, Salvador, jan./abr. 2012, pp.63-71.

. O Tema do desenvolvimento na Antropologia Brasileira: diálogo com Antropólogos. Sociedade, política e desenvolvimento. In: MONTEIRO NETO, Aristides (org.). Desenvolvimento nas ciências sociais. Sociedade Política e Desenvolvimento, Livro 2. Brasília, Ipea, 2014, pp.197-220. 
BARCARENA. Lei Municipal $n^{\circ}$ 2200/2017, de 26 de dezembro de 2017 [https://www.barcarena.pa.gov.br/.../84_LEIMUNICIPAL2200INSTIT UIOPPA2018202 - acesso em: 11 out. 2018].

BRAH, Avtar. Diferença, diversidade, diferenciação. cadernos pagu (26), Campinas, SP, Núcleo de Estudos de Gênero-Pagu/Unicamp, 2006, pp.329-376.

BRASIL. Ministério do Interior. Superintendência do Desenvolvimento da Amazônia. Complexo Alumínio Albrás/Alunorte. Programa Especial de Desenvolvimento Regional Infraestrutura do Complexo AlumínioAlbrás/Alunorte. SUDAM, 1979 (Série Programas Especiais 2, 31.12).

BRITO, D. C. Modernização da superfície. Estado e Desenvolvimento na Amazônia. Belém-PA, UFPA; NAEA, 2001.

CAmURÇA, S. M. S. Sobre o problema das desigualdades de gênero no desenvolvimento e para a democracia. In: CAMURÇA, Silvia Maria Sampaio et alii (org.). Perspectiva de Gênero. Debates e Questões para ONGS vol. 1. Recife, Plataforma NOVIB/ SOS Corpo, 2002, pp.164-175.

EstevA, Gustavo. Development. In: SACHS, Wolfang (ed.). The Development Dictionary. London Zed Books, 1992, pp.6-25.

FouCAUlT, Michel. Segurança, território, população: curso dado no Collège de France (1977-1978). São Paulo, Martins Fontes, 2008.

LOBO, Marco Aurélio Arbage. Estado e capital transnacional na Amazônia: o caso da Albrás-Alunorte. Belém, PA, UFPA; NAEA, 1996.

MAIA, Rosane de Oliveira Martins. Territorialidades específicas em Barcarena confrontadas com projetos de "desenvolvimento". Tese (Doutorado em Ciência do Desenvolvimento Socioambiental), Núcleo de Altos Estudos Amazônicos, Programa de Pós-Graduação em Desenvolvimento Sustentável do Trópico Úmido, Universidade Federal do Pará, Belém, 2017.

MaIA, Rosane de Oliveira Martins; ACEvedo Marin, Rosa Elizabeth. $A$ arte da resistência de comunidades tradicionais em Barcarena (Pará) face à ordem do progresso industrial. In: Anais do $38^{\circ}$ Encontro Anual da ANPOCS - GT07 - Conflitos ambientais, Estado e ideologia do desenvolvimento: mediação e luta por direitos. Caxambu, MG, 
outubro de 2014 [https://anpocs.com/index.php/papers-38encontro/gt-1/gt07-1?format $=\mathrm{html}-$ acesso em: 11 out. 2018].

MONTEIRO, Maurílio. Meio século de mineração industrial na Amazônia e suas implicações para o desenvolvimento regional. Estudos Avançados n 19, vol. 53, São Paulo, IEA USP, 2005, pp.187-208.

MouRA, Edila A. F.; MAIA, Maria L.S.; ABELÉM, Auriléa (col.). A reorganização do espaço de trabalho e do espaço doméstico das familias de Barcarena: os efeitos do Projeto ALBRAS-ALUNORTE. Belém, PA, 1989.

OliveIRA, João Pacheco de et alii. O tema do Desenvolvimento na Antropologia Brasileira. Diálogos com Antropólogos. In: MONTEIRO NETO, Aristides (org.). Sociedade, política e desenvolvimento. Brasília, Ipea, 2014, pp.197-220.

PALHETA, Rosiane Pinheiro. Movimentos sociais e reivindicações populares em torno das empresas de transformação mineral em Barcarena: um estudo da atuação das associações de moradores $e$ trabalhadores rurais. Dissertação (Mestrado em Planejamento do Desenvolvimento), Núcleo de Altos Estudos Amazônicos, NAEA/UFPA, Belém, 2004.

SCOTT, James C. Exploração normal, resistência normal. Revista Brasileira de Ciência Politica n 5, Brasilia, DF, jan.jjul. 2011, pp.217243 [http://www.scielo.br/scielo.php?script=sci_arttext\&pid=S010333522011000100009].

. Los dominados y el arte de la resistencia. Discursos ocultos. México, Era, 2004. [Tradução: Jorge Aguilar Mora].

. Everyday forms of Peasant Resistance. Journal of Peasant Studies vol. 13, n 2, 1986, pp.5-35.

SCOTT, Joan W. Gênero: uma categoria útil de análise histórica. Educação \& Realidade 20 (2), julho-dezembro, 1995, pp.71-99.

. "La querele des femmes" no final do século XX. Revista de Estudos Feministas vol. 9, n² 2, 2001, pp.367-388.

TOURINHO, Helena Lúcia Zagury. Repercussóes socioeconômicas do Complexo Industrial ALBRÁS/ALUNORTE em sua área de influência. Belém, IDESP, 1991. 